\title{
MATERNAL AGEING AND EMBRYONIC MORTALITY IN THE RABBIT
}

\section{HORMONAL GHANGES IN YOUNG AND AGEING FEMALES}

\author{
R. R. MAURER* AND R. H. FOOTE
}

Department of Animal Science, Cornell University, Ithaca, New York 14850, U.S.A.

(Received 10th August 1971, accepted 24th Fanuary 1972)

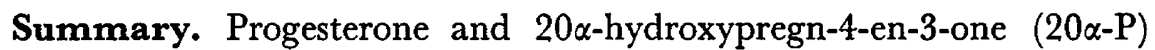
synthesis in vivo and in vitro was measured 12 days post coitum in does averaging 32 weeks (young) and 214 weeks old (ageing). Young pregnant does had an average of 7.7 corpora lutea and 7.3 implantations for a mortality rate of $4.3 \%$. Similar values for ageing does were $7 \cdot 7,5.4$ and $29 \%$, respectively. The progesterone content of ovarian venous blood was higher in young pregnant does than ageing does but the $20 \alpha-\mathrm{P}$ content did not differ. Administration of LH did not significantly alter progesterone blood levels in either age group but increased $20 \alpha-\mathrm{P}$ levels in both groups. Synthesis of progesterone and $20 \alpha-\mathrm{P}$ by interstitial tissue in vitro did not differ significantly between ages. Addition of LH to the incubation medium stimulated synthesis of progesterone by tissue from the ageing group whereas $20 \alpha-P$ synthesis was increased in the young group. There was a positive relationship between doe age and pituitary weight. The ageing does had heavier pituitary glands than the young does but there was no difference in total LH content.

A lower concentration of $\mathrm{LH}$ was found in the pituitary gland and a lower progesterone content in the ovarian venous blood of old compared to young pregnant rabbits. While these differences may be partly responsible for the lowered reproductive efficiency of the ageing female, the evidence is somewhat equivocal since total pituitary LH and synthesis of progesterone in vitro were similar in the two age groups.

\section{INTRODUCTION}

The decrease in reproductive efficiency with increasing maternal age has been attributed mainly to an inadequate maternal milieu (Boot \& Mühlbock, 1954; Krohn, 1962; Adams, 1964, 1970; Blaha, 1964; Talbert, 1968; Maurer \& Foote, 1971). Burrows (1940) found excessive oestrogen secretion in older rabbits and suggested a malfunction of the hypothalamus. Aschheim (1964/65)

* Present address: National Institute of Environmental Health Sciences, P.O. 12233, Research Triangle Park, North Garolina 27709. 
demonstrated that senile modifications of the rat oestrous cycle may be due to a hypothalamic change.

Mandl (1959) found an increase in the size of corpora lutea due mainly to enlarged luteal cells in senile rats. Recently, Harman \& Talbert (1970) and Talbert (1971) suggested that a deficiency in the corpus luteum function of C57BL/6J mice with increased maternal age caused an increase in embryonic mortality.

In this investigation, pituitary luteinizing hormone (LH), pregn-4-en-3-one

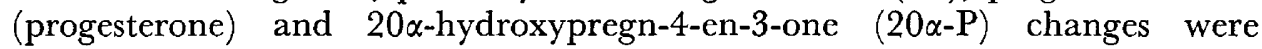
examined in young and ageing female rabbits and related to reproductive performance.

\section{MATERIALS AND METHODS}

Material was collected from seventeen uniparous young rabbits of 5 to 10 months of age, and twenty-two multiparous does of 3 years or older. Animals were housed and fed as described previously (Maurer \& Foote, 1971).

All does were mated naturally to males of proven fertility. Twelve days post coitum (p.c.), young and old does were anaesthetized with sodium pentobarbitone. A femoral vein was cannulated and 2000 units heparin were infused. The linea alba was surgically opened and one ovarian vein was cannulated using polyethylene tubing (PE 50). Control blood was collected for $20 \mathrm{~min}$; each doe then received a single injection of $250 \mu \mathrm{g}$ NIH-LH-B 5 in $0.25 \mathrm{ml}$ physiological saline followed by $0.50 \mathrm{ml}$ saline by way of a femoral vein cannula. Blood was collected for two additional 20 -min intervals. Blood volume was maintained by infusing $5 \%$ dextrose in physiological saline at a rate comparable to blood removal. The heparinized ovarian blood was centrifuged at 3000 $\mathrm{rev} / \mathrm{min}$ for $15 \mathrm{~min}$. The plasma was decanted off, labelled and frozen for 2 to 6 weeks until it was analysed for progesterone and $20 \alpha-P$.

The contralateral ovary was removed in each of five young and three old does for steroidogenesis analysis in vitro. The corpora lutea and Graafian follicles were removed. The interstitial tissue was proportioned into three groups: untreated unincubated control, incubated control and incubated with $12 \mu \mathrm{g} \mathrm{LH} / \mathrm{ml}$ of medium. Tissue was placed in $4 \mathrm{ml} \mathrm{Krebs-Ringer} \mathrm{bicarbonate}$ buffer containing $1 \mathrm{mg}$ glucose $/ \mathrm{ml}$ and $0.6 \mu \mathrm{Ci}\left[{ }^{14} \mathrm{C}\right]$ acetate $/ \mathrm{ml}$. The buffer was gassed with $95 \% \mathrm{O}_{2}: 5 \% \mathrm{CO}_{2}$ for 15 min before being placed in the flasks and again for $30 \mathrm{sec}$ after receiving the respective tissue. All flasks were stoppered and those to be incubated were incubated for $4 \mathrm{hr}$ at $37^{\circ} \mathrm{C}$. All unincubated flasks were frozen immediately on dry ice and, $4 \mathrm{hr}$ later, the incubated flasks were similarly frozen until assayed for progesterone and $20 \alpha-P$.

The progesterone and $20 \alpha-\mathrm{P}$ content of blood plasma and ovarian tissue samples were chromatographed three times and determined according to the methods described by Armstrong, O'Brien \& Greep (1964) and Solod, Armstrong \& Greep (1966). The amount of steroid in each aliquot was determined with a spectrophotometer and adjusted, using the Allen correction. Progesterone and $20 \alpha-\mathrm{P}$ values were corrected for recovery losses, using radioactive steroids.

Upon completion of the blood collection, each doe was killed with an over- 
dose of sodium pentobarbitone. The pituitary was removed, weighed and immediately frozen on dry ice. The ovarian ascorbic acid depletion method (Parlow, 1961) was used to assay the pituitaries for LH. Each pituitary was homogenized and diluted with physiological saline to concentrations of 0.4 and $1.6 \mathrm{mg}$ tissue $/ \mathrm{ml}$. Bovine NrH-LH-B5 was used as the standard with levels of $0.4,1.6$ and $6.4 \mu \mathrm{g} / \mathrm{ml}$. Five Carworth CFE-strain female rats were used per level. The ovarian ascorbic acid content was determined by the 2,4 dinitrophenylhydrazine method according to Bessey, Lowry \& Brock (1947). The results were analysed statistically by the method of Finney (1952).

The diameters of the implantation sites were measured and the developing conceptuses examined.

\section{RESULTS}

The percentage of the seventeen naturally mated young does which were pregnant, pseudopregnant and non-pregnant was $70 \cdot 6,11.8$ and 17.6, respectively. Similar results for the twenty-two ageing does were $40 \cdot 9,27 \cdot 3$ and $31.8 \%$, respectively. Both young and ageing pregnant does had an average of 7.7 corpora lutea, but the young does had an average of $95.7 \%$ implantation sites versus $71.0 \%$ for the ageing does $(P<0 \cdot 10)$. The average diameter of the implantation sites in ageing does was significantly larger $(17.9$ versus $16.1 \mathrm{~mm}$, $P<0.05)$. All developing conceptuses appeared to be normal and no gross congenital aberrations were found.

Steroid synthesis in vivo

The results of the steroidogenesis in vivo are presented in Table 1. The young pregnant does had a higher $(P<0 \cdot 005)$ control and overall progesterone secretion rate than the ageing does. The injected $L H$ did not significantly increase $(P>0 \cdot 10)$ progesterone secretion in either age group. No significant difference $(P>0 \cdot 10)$ for $20 \alpha-P$ production in vivo between ages were found. However, the exogenous LH significantly increased $(P<0 \cdot 05) 20 \alpha-P$ production in both the young and ageing does. Secretion of $20 \alpha-\mathrm{P}$ by pregnant does was higher $(P<0 \cdot 05)$ than for pseudopregnant and non-pregnant does. The secretion rates of progestins found in the pseudopregnant does tended to parallel those found in the pregnant does. Results with a limited number of non-pregnant does were generally similar to those obtained with pseudopregnant does. Ovarian venous blood flow from pregnant, pseudopregnant and non-pregnant young does was $0.59,0.32$ and $0.41 \mathrm{ml} / \mathrm{min}$, respectively. Similar values for the ageing does were $0.51,0.51$ and $0.51 \mathrm{ml} / \mathrm{min}$.

Steroid synthesis in vitro

Table 2 lists the results of incubation in vitro of interstitial tissue from young and ageing pregnant does. No significant difference $(P>0 \cdot 10)$ was found between ages in progestin synthesis. Exogenous LH stimulated the interstitial tissue to synthesize and/or release more $(P<0.05)$ progestins in both the ageing and young does. The young does appeared to synthesize progestins as indicated by the decrease in counts $/ \mathrm{min} / \mu \mathrm{g}$ progestin in the $\left[{ }^{14} \mathrm{C}\right]$ acetate study. The ageing does may have had more stored steroid precursors, as indicated by the 


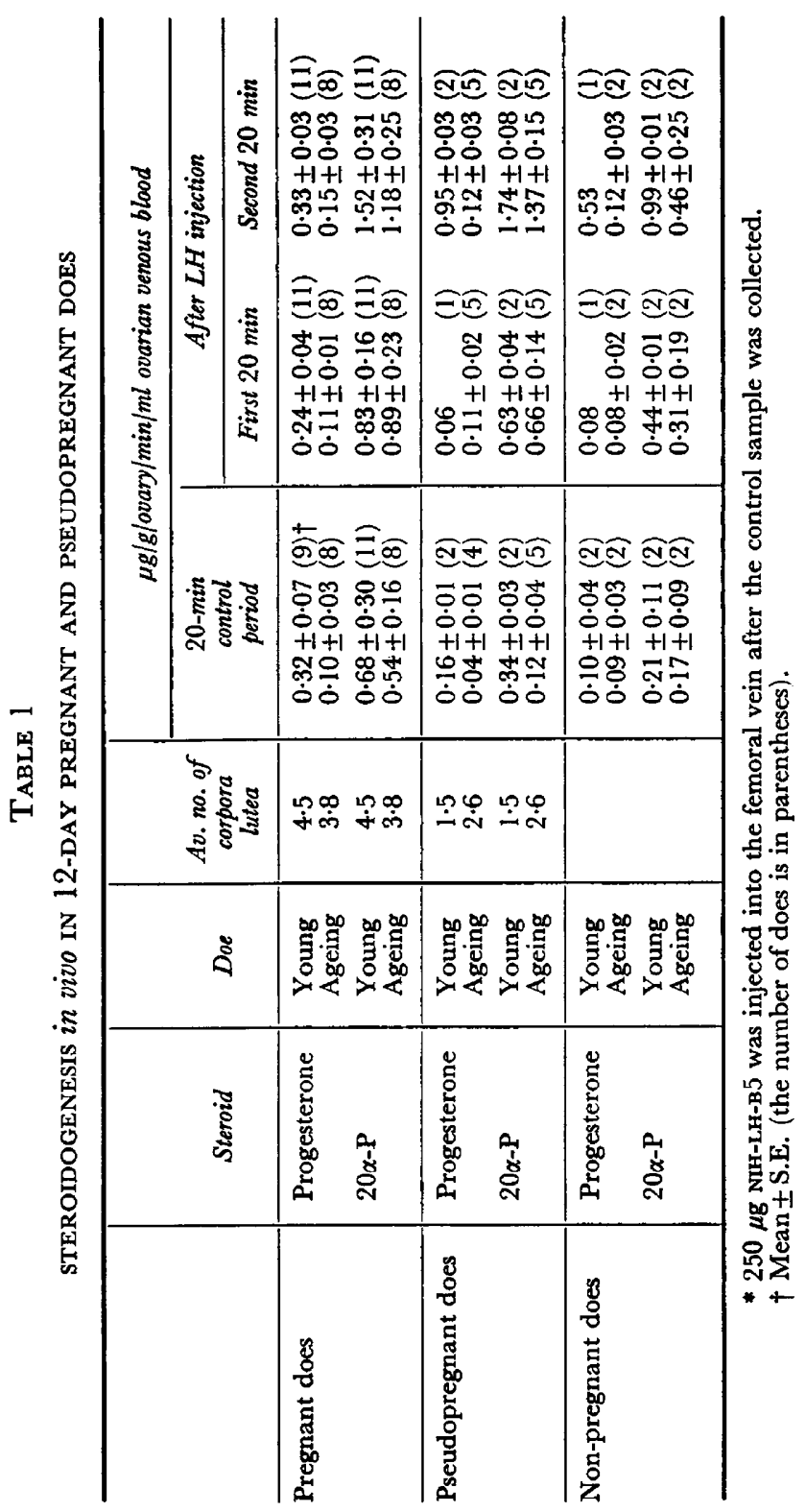


low incorporation of $\left[{ }^{14} \mathrm{G}\right]$ acetate during incubation. However, initial tissue concentration of progestins from different does was found to vary considerably $(P<0.05)$, indicating a large difference in ability to respond.

TABLE 2

STEROIDOGENESIS in vitro IN INTERSTITIAL TISSUE FROM 12-DAY PREGNANT YOUNG AND AGEING DOES

\begin{tabular}{|c|c|c|c|c|}
\hline \multirow[t]{2}{*}{ Doe* } & Steroid & $\begin{array}{l}\text { Unincubated } \\
\text { control }\end{array}$ & \multicolumn{2}{|c|}{ Incubated } \\
\hline & & \multicolumn{3}{|c|}{$\mu \mathrm{g}$ steroid/g tissue } \\
\hline Young & $\begin{array}{l}\text { Progesterone } \\
20 x-\mathrm{P}\end{array}$ & $\begin{array}{c}157 \pm 72 \dagger \\
64 \pm 19\end{array}$ & $\begin{array}{r}195 \pm 48 \\
94 \pm 34\end{array}$ & $\begin{array}{l}510 \pm 210 \\
208 \pm 72\end{array}$ \\
\hline \multirow[t]{2}{*}{ Ageing } & $\begin{array}{l}\text { Progesterone } \\
20 \alpha-\mathrm{P}\end{array}$ & $\begin{array}{l}60 \pm 22 \\
91 \pm 67\end{array}$ & $\begin{array}{r}142 \pm 58 \\
89 \pm 26\end{array}$ & $\begin{array}{l}217 \pm 101 \\
166 \pm 53\end{array}$ \\
\hline & & \multicolumn{3}{|c|}{$\begin{array}{c}{\left[{ }^{14} \mathrm{C}\right] \text { acetate incorporation }} \\
\text { (counts } / \mathrm{min} / \mu \mathrm{g} \text { steroid })\end{array}$} \\
\hline Young & $\begin{array}{l}\text { Progesterone } \\
20 \alpha-\mathrm{P}\end{array}$ & $\begin{array}{l}7 \pm 3 \\
1 \pm 0 \cdot 3\end{array}$ & $\begin{array}{l}33 \pm 12 \\
26 \pm 14\end{array}$ & $\begin{array}{l}15 \pm 6 \\
15 \pm 6\end{array}$ \\
\hline Ageing & $\begin{array}{l}\text { Progesterone } \\
20 \alpha-\mathrm{P}\end{array}$ & $\begin{array}{l}2 \pm 2 \\
1 \pm 1\end{array}$ & $\begin{array}{l}6 \pm 1 \\
8 \pm 1\end{array}$ & $\begin{array}{r}9 \pm 2 \\
15 \pm 6\end{array}$ \\
\hline
\end{tabular}

* Five young does averaged 38 weeks of age. Three ageing does averaged 174 weeks of age.

$\dagger$ Mean \pm S.E.

TABLE 3

PITUITARY LH GONTENT IN YOUNG AND AGEING DOES 12 DAYs post coitum

\begin{tabular}{|c|c|c|c|c|c|c|}
\hline \multirow[b]{2}{*}{ Criteria } & \multicolumn{3}{|c|}{ roung does } & \multicolumn{3}{|c|}{ Ageing does } \\
\hline & Pregnant & $\begin{array}{l}\text { Pseudo- } \\
\text { pregnant }\end{array}$ & $\underset{\text { pregnant }}{\text { Non- }}$ & Pregnant & $\begin{array}{l}\text { Pseudo- } \\
\text { pregnant }\end{array}$ & $\underset{\text { pregnant }}{\text { Non- }}$ \\
\hline No. of does & 10 & 2 & 3 & 6 & 3 & 6 \\
\hline No. of corpora lutea & $7 \cdot 8 \pm 0 \cdot 7^{*}$ & $3 \cdot 0 \pm 2 \cdot 0$ & $0 \pm 0$ & $8 \cdot 2 \pm 0 \cdot 5$ & $4 \cdot 7 \pm 1 \cdot 9$ & $0 \pm 0$ \\
\hline Pituitary wet wt (mg) & $26 \cdot 3 \pm 1 \cdot 5$ & $24 \cdot 9 \pm 4 \cdot 1$ & $16.8 \pm 0.9$ & $58 \cdot 0 \pm 4 \cdot 9$ & $44 \cdot 4 \pm 6 \cdot 5$ & $35 \cdot 2 \pm 2 \cdot 4$ \\
\hline $\begin{array}{l}\text { LH potency }{ }_{(\mu \mathrm{g} / \mathrm{mg} \text { wet } w \mathrm{t})}\end{array}$ & $3 \cdot 2 \pm 0.5$ & $1.6 \pm 0.7$ & $3 \cdot 0 \pm 0.2$ & $1 \cdot 6 \pm 0 \cdot 2$ & $1 \cdot 3 \pm 0 \cdot 3$ & $1 \cdot 4 \pm 0.3$ \\
\hline Total LH content $(\mu \mathrm{g})$ & $85 \cdot 3 \pm 13 \cdot 4$ & $42 \cdot 8 \pm 24 \cdot 0$ & $50 \cdot 6 \pm 6 \cdot 8$ & $95 \cdot 8 \pm 17 \cdot 2$ & $61 \cdot 2 \pm 20 \cdot 4$ & $47 \cdot 8 \pm 7 \cdot 8$ \\
\hline
\end{tabular}

* Mean \pm S.E.

$\dagger$ Based upon NIH-LH-B5 standard.

\section{Pituitary $L H$}

Results are presented in Table 3 . The group means were adjusted by the method of fitting constants before applying the analysis of variance. Overall, the ageing females had significantly heavier pituitary glands $(P<0.005)$ and a significantly lower pituitary LH concentration/mg wet weight $(P<0.005)$ than younger does, but the two groups did not differ in total LH content $(P>0 \cdot 10)$. Taking the average of both age groups, pregnant does had larger pituitary glands and more total LH than non-pregnant does $(P<0.05)$. Pituitary wet 
weight was correlated with the age of the doe $(\mathrm{r}=0.66, P<0.01)$, but not with the number of corpora lutea $(\mathrm{r}=0.20, P>0.10)$. However, the multiple correlation among doe age, number of corpora lutea and pituitary wet weight was $\mathrm{r}=0.82(P<0.05)$.

In the ageing group, only two does had either an ovarian cyst or a diseased uterine horn. This is a lower incidence than that found by Adams (1970) who reported that in $55 \%$ of does of similar age, either one or both uterine horns diseased.

\section{DISCUSSION}

The ageing does showed a marked reduction in reproductive efficiency when compared to the young does. In the ageing group, there were $29.7 \%$ fewer pregnancies and $24.7 \%$ more embryonic mortality 12 days p.c.

Steroid synthesis in vivo and in vitro

Three important events take place in the rabbit uterus during implantation: (1) mechanical spacing of the blastocysts, (2) adhesion to the endometrial epithelium, and (3) invasion of the endometrial epithelium (Boving, 1967). These changes are partially dependent upon progesterone which, in turn, is governed by the hypothalamus by way of the pituitary and ovary. Beier, Petry \& Kühnel (1970) have shown that rabbit uterine uteroglobin and $\beta$-glycoprotein secretion rates are progesterone-dependent. Harman \& Talbert (1970) and Talbert (1971) suggested that luteal function is reduced in old pregnant C57BL/6J mice. However, Finn (1963), using a functional test, concluded that progesterone deficiency was an unlikely cause of uterine insufficiency.

In the present investigation, the ageing does had lower levels of progesterone in ovarian venous blood than the younger does $(P<0.05)$. Initial progesterone content and synthesis during incubation with LH in vitro (Table 2) tended to be lower in ageing does, but the differences were not statistically significant. These differences in progesterone levels may have been responsible, in part, for the decreased incidence of pregnancy and increased rate of embryo mortality observed 12 days p.c. in the ageing does.

The function of rabbit corpora lutea is oestrogen-dependent (Keyes \& Nalbandov, 1967). With a decrease in the primary oocyte population as the female ages, there may have been a decrease in oestrogen synthesis. However, the number of Graafian follicles appeared to be similar in the two age groups as judged by ovulation rates (number of corpora lutea).

Interstitial tissue in vitro produced more progesterone than $20 \alpha-\mathrm{P}$ in both age groups. This is contrary to earlier reports (Solod et al., 1966; Hilliard, Spies \& Sawyer, 1968). The interstitial tissue of pregnant rabbits has also been reported to contain more 20 $\alpha$-P than progesterone (Rathmacher \& Anderson, 1971). The amount of LH added to the incubated tissue was higher than has previously been reported, however, and this level of LH, coupled with a decrease in $20 \alpha-$ hydroxysteroid dehydrogenase activity, could have caused more progesterone to be produced, since progesterone is the precursor of $20 \alpha-P$. The $20 \alpha$-hydroxysteroid dehydrogenase activity is reported to be lowest during the luteal phase (Wiest, 1959; Wiest, Wilcox \& Kirschbaum, 1963). 
Guraya (1967) found that some rabbit interstitial cells become refractory to gonadotrophic stimulation and do not release their lipids. If refractoriness increased with age, a decreased synthesis could result.

\section{Pituitary $L H$ content}

The increase in pituitary wet weight and lower $(P<0.05)$ potency in the ageing animals indicates a possible decrease in cellular efficiency and/or response of the pituitary to lower steroid levels. The significantly higher pituitary wet weight and LH content in pregnant and pseudopregnant animals suggest that pregnancy acts as a stimulus. Orsini \& Schwartz (1970) have shown that there is a rise in LH content until the end of pseudopregnancy in hamsters and that pituitary wet weights are higher than in cyclic animals. These data indicate that the differences in LH levels in young and ageing does may be responsible, in part, for the differences observed in the progesterone content of ovarian venous blood. However, the nature of this relationship remains equivocal until data are available on the concentration of peripheral plasma LH in different physiological states of young and old does.

\section{AGKNOWLEDGMENTS}

This investigation was supported in part by Grant HD 03471 from the National Institute of Child Health and Human Development, USPHS. The authors are grateful to Dr R. G. Jones, Mr Bruce Hakes and Mr Michael Simkin, for their assistance in collecting and analysing the data. They are also grateful to the Endocrine Study Section of the National Institute of Health for supplying purified bovine LH.

\section{REFERENCES}

ADAMS, C. E. (1964) The influence of advanced maternal age on embryo survival in the rabbit. 5 th int. Congr. Animal Reprod. A.I. 2, 305.

ADAms, C. E. (1970) Ageing and reproduction in the female mammal with particular reference to the rabbit. F. Reprod. Fert., Suppl. 12, 1.

Armstrong, D. T., O'Brien, J. \& GreEp, R. O. (1964) Effects of luteinizing hormone on progestin biosynthesis in the luteinized rat ovary. Endocrinology, 75, 488.

AschHeim, P. (1964/65) Résultats fournis par la greefe hétérochrone des ovaires dans l'étude de la régulation hypothalamo-hypophyso-ovarienne de la ratte sénile. Gerontologia, 10, 65.

Beier, H. M., Petry, G. \& Kühnel, W. (1970) Endometrial secretion and early mammalian development. In: Mammalian Reproduction. Eds. H. Gibian and E. J. Plotz. Springer, New York.

Bessey, O. A., Lowry, O. H. \& Brock, M. J. (1947) The quantitative determination of ascorbic acid in small amounts of white blood cells and platelets. F. biol. Chem. 168, 197.

BLAHA, G. G. (1964) Effect of age of the donor and recipient on the development of transferred golden hamster ova. Anat. Rec. 150, 413.

Bоот, L. M. \& MüнLвоск, O. (1954) The ovarian function in old mice. Acta physiol. pharmac. néerl. 3, 463.

Boving, B. G. (1967) Chemo-mechanics of implantation. In: Comparative Aspects of Reproductive Failure, p. 142. Ed. Kurt Benirschke. Springer, New York.

Burrows, H. (1940) Spontaneous uterine and mammary tumors in the rabbit. F. Path. Bact. 51, 385.

FinN, C. A. (1963) Reproductive capacity and litter size in mice: effect of age and environment. $\mathcal{F}$. Reprod. Fert. 6, 205.

Finney, D. J. (1952) Statistical method in biological assay. Charles Griffin, London.

Guraya, S. S. (1967) Cytochemical observations concerning the formation, release, and transport of lipid secretory products in the interstitial (thecal) cells of the rabbit ovary. Z. Zellforsch. mikrosk. Anat. 83, 187. 
Harman, S. M. \& TAlbert, G. B. (1970) The effect of maternal age on ovulation, corpora lutea of pregnancy, and implantation failure in mice. F. Reprod. Fert. $23,33$.

Hilliard, J., Spies, H. G. \& SaWyer, C. H. (1968) Cholesterol storage and progestin secretion during pregnancy and pseudo-pregnancy in the rabbit. Endocrinology, 82, 157.

Keyes, P. L. \& Nalbandov, A. V. (1967) Maintenance and function of corpora lutea in rabbits depend on estrogen. Endocrinology, 80, 938.

Kroнn, P. L. (1962) Heterochronic transplantation in the study of ageing. Proc. R. Soc. B, 157, 128.

MANDL, A. (1959) Corpora lutea in senile virgin laboratory rats. F. Endocr. 18, 438.

MAurer, R. R. \& Foote, R. H. (1971) Maternal ageing and embryonic mortality in the rabbit. I. Repeated superovulation, embryo culture and transfer. F. Reprod. Fert. 25, 329.

Orsini, M. W. \& Schwartz, N. B. (1970) Uterine weight and pituitary LH content in the pseudopregnant hamster. F. Reprod. Fert. 22, 431.

PARLow, A. F. (1961) Bioassay of pituitary luteinizing hormone by depletion of ovarian ascorbic acid. In: Human Pituitary Gonadotropins, p. 300. Ed. A. Albert. Thomas, Springfield.

Rathmacher, R. P. \& Anderson, L. L. (1971) Blood flow and progestin levels in the ovaries of pregnant rabbits. Endocrinology, 88, 821.

Solod, E. A., Armstrong, D. T. \& Greep, R. O. (1966) Action of luteinizing hormone on conversion of ovarian cholesterol stores to steroids secreted in vivo and synthesized in vitro by the pseudopregnant rabbit ovary. Steroids, 7, 607.

TAlbert, G. B. (1968) Effect of maternal age on reproductive capacity. Am. F. Obstet. Gynec. 102, 451.

TALBERT, G. B. (1971) Effect of maternal age on postimplantation reproductive failure in mice. $\mathcal{J}$. Reprod. Fert. 24, 449.

WIEST, W. G. (1959) Conversion of progesterone to 4-pregnen-20 $\alpha$-ol-3-one by rat ovarian tissue in vitro. 7. biol. Chem. 234, 3115.

Wiest, W. G., Wilcox, R. B. \& Kirschiaum, T. H. (1963) Rat ovarian 20 $\alpha$-hydroxysteroid dehydrogenase: effects of estrogens and pituitary gonadotrophins. Endocrinology, 73, 588. 